\title{
SURGICAL CORRECTION OF POST-TRAUMATIC KYPHOSIS WITH OSTEOTOMIES IN THE SPINE
}

\author{
CORREÇÃO CIRÚRGICA DA CIFOSE PÓS-TRAUMÁTICA COM O USO DE OSTEOTOMIAS \\ NA COLUNA ESPINAL
}

\section{CORRECCIÓN QUIRÚRGICA DE CIFOSIS POSTRAUMÁTICA CON OSTEOTOMÍAS EN LA COLUMNA VERTEBRAL}

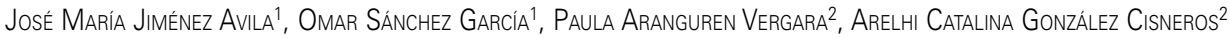 \\ 1. Instituto Mexicano del Seguro Social, Centro Médico Nacional de Occidente, Spine Clinic, Guadalajara, Jalisco, Mexico. \\ 2. Instituto Tecnológico y de Estudios Superiores de Monterrey, Escuela de Medicina y Ciencias de la Salud, Guadalajara, Jalisco, Mexico.
}

\begin{abstract}
Objective: To analyze the clinical and radiological evolution, indications and complications of the types of osteotomies in patients with disturbed sagittal balance (SB) resulting from post-traumatic kyphosis. The SB can be measured with a plumb line from the center of the body of $\mathrm{C} 7$ to $\mathrm{S1}$, which allows recognizing the misalignment. The imbalance can be corrected by osteotomy. Methods: Thirty patients with SB loss due to post-traumatic kyphosis were studied from January 2014 to December 2017. SPO, PSO and VCR were performed to evaluate the degree of kyphosis before and after surgery, the Oswestry questionnaire was applied and the degree of correction, the days of hospital stay and transoperative bleeding were assessed. Results: Age, 50 years, SD = 14, follow-up time: 2-3 years. We performed 11 (36.7\%) osteotomies of S-P, 17 (56.7\%) pedicle subtractions and $2(6.6 \%)$ vertebrectomies. Most of the lesions were found between levels $\mathrm{L} 1$ and $\mathrm{L} 2$; the complications were dehiscence of the surgical wound in 4 patients (13.3\%) and infection in $2(6.6 \%)$. The minimum surgical time was 3 hours; the Oswestry questionnaire did not showed statistically significant difference during the preoperative period, however, considerable improvement was observed 2 years after surgery. Conclusions: The use of corrective vertebral osteotomies significantly reestablishes the spinopelvic balance altered by different pathologies. It allows correcting in a single surgery the sagittal balance, achieving corrections from $10^{\circ}$ to $40^{\circ}$, depending on the type of osteotomy performed, being a safe and effective procedure, which allows to restore the spinopelvic balance, improving the quality of life of the patients. Level of Evidence Ilb; Prospective cohort study.
\end{abstract}

Keywords: Osteotomy; Post-traumatic Kyphosis; Postural balance.

\section{RESUMO}

Objetivo: Analisar a evolução clínica, radiológica, indicações e complicações dos tipos de osteotomias em pacientes com desequilíbrio no equilíbrio sagital (ES), por uma cifose pós-traumática. O ES é o fio de prumo que vai do centro do corpo do C7 e permite reconhecer um mau alinhamento. Isso pode ser corrigido por osteotomia. Métodos: 30 pacientes foram estudados com perda no ES por cifose pós-traumático entre Janeiro de 2014 e Dezembro de 2017. SPO, PSO e VCR foram realizados, em que foi avaliado o grau de cifose pré e pós-operatório, o questionário Oswestry foi aplicado para avaliar o grau de correção, dias de internação e sangramento transoperatório. Resultados: Idade: 50 anos d.s. 14, tempo de seguimento: 2-3 anos. Foram realizados 11 (36,7\%) osteotomías de SP, 17 (56,7\%) subtracção de pedículo e 2 (6,6\%) vertebrectomias, a maioria das lesões foi encontrada entre os níveis de L1 e L2; complicações: deiscência da ferida operatória em 4 pacientes (13,3\%) e infecção em 2 (6,6\%). Tempo cirúrgico mínimo: 3 horas; Oswestry questionário: não houve diferença estatisticamente significativa no pré-operatório, no entanto, no pós-operatório, em 2 anos, há uma melhoria considerável. Conclusão: A utilização de osteotomias correctiva a nível vertebral, restaura o equilíbrio espinopélvico significativamente, alterados por diferentes patologias. Corrige em um único tempo cirúrgico o equilíbrio sagital, fazendo correções da $10^{\circ}$ a $40^{\circ}$, dependendo do tipo de osteotomia, sendo um procedimento seguro e eficaz, que permite espinopélvico restaurar o equilíbrio, melhorando a qualidade de vida dos pacientes. Nível de Evidência Ilb; Estudo prospectivo de coorte.

Descritores: Osteotomia; Cifose pós-traumática; Equilíbrio postural

\section{RESUMEN}

Objetivo: Analizar la evolución clínica y radiológica, indicaciones y complicaciones de los tipos de osteotomías en pacientes con desequilibro del balance sagital (BS) resultante de cifosis postraumática. El BS se puede medir con una línea de plomada desde el centro del cuerpo de C7 hasta S1, que permite reconocer la mala alineación. El desequilibrio puede ser corregido mediante osteotomía. Métodos: Se estudiaron 30 pacientes con pérdida del BS por cifosis postraumática en el período de enero 2014 a diciembre 2017. Se realizaron SPO, PSO y VCR para evaluar el grado de cifosis pre y postquirúrgica, se aplicó el cuestionario de Oswestry, se valoró el grado de corrección, los días de estancia hospitalaria y el sangrado transoperatorio. Resultados: Edad, 50 años, DE = 14, tiempo de seguimiento, 2-3 años. Se realizaron 11 (36,7\%) Osteotomias de Smith-Petersen, 17 (56,7\%) sustracciones pediculares y 2 (6,6\%) vertebrectomías. La mayoría de las lesiones se encontró entre los niveles L1 y L2; las complicaciones fueron dehiscencia de la herida quirúrgica en 4 pacientes $(13,3 \%)$ e infección en 2 (6,6\%). El tiempo quirúrgico mínimo fue de 3 horas; el Cuestionario de Oswestry no presentó diferencia estadísticamente

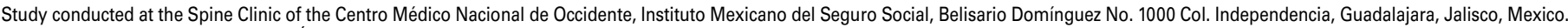
Correspondence José María Jiménez Ávila. Belisario Domínguez, 1000, Col. Independencia, Guadalajara, Jal., México. 44340. josemajimeneza@ @otmail.com 
significativa durante el preoperatorio, sin embargo, a los 2 años postoperatorios se observa mejoría considerable. Conclusiones: El uso de osteotomías vertebrales correctoras restablece significativamente el equilibrio espinopélvico alterado por diferentes patologías. Permite corregir en un solo tiempo quirúrgico el balance sagital, logrando correcciones de $10^{\circ} \mathrm{a} 40^{\circ}$, dependiendo del tipo de osteotomía realizada, siendo un procedimiento seguro y efectivo, que permite restaurar el equilibrio espinopélvico, mejorando la calidad de vida de los pacientes. Nivel de evidencia IIb; Estudio de cohorte prospectivo.

Descriptores: Osteotomía; Cifosis postraumática; Balance postural.

\section{INTRODUCTION}

Sagittal balance (SB) is defined as the plumb line that runs from the center of the body of $\mathrm{C} 7$ and falls plus or minus $2 \mathrm{~cm}$ from the anterior part of the sacral promontory and is used to locate the position of the head in relation to the normal center of gravity (Figure 1). ${ }^{1}$

Identifying this measurement is relevant to the diagnosis and treatment of the various pathologies that affect the spine, given that, by not identifying and not recognizing misalignment of this plane, there is a risk that patients will have deformities that can cause disability or limiting pain that affects quality of life.

Deformity can cause the loss of this balance, which can be classified as Type I, where the loss of balance is segmental and one portion of the spine is in hyperlordosis or kyphosis, but the balance is satisfactory, or Type II, where the loss of balance occurs when the patient cannot compensate. Another important factor is whether the deformity is located in the thoracic or lumbar spine. ${ }^{2,3}$

SB can be measured radiologically, allowing assessment of spinal balance and permitting the identification of the degrees of correction that are required in the case of spinal deformity. This can help classify the deformity according to the categories of a) totally flexible, b) partially flexible, and c) rigid. ${ }^{4}$

Post-traumatic kyphosis is defined as that deformity that presents axial pain or neurological deterioration and that keeps patients symptomatic, resulting from misalignment from the sequela of a complication of treatment of spinal fractures, the main causes of which are non-recognized instability at the beginning of the fracture, poor reduction at the beginning of treatment, pseudoarthrosis, and the premature removal of the implants. 5,6

There are multiple techniques for the correction of SB, among them the Smith-Petersen (SPO) or Ponte osteotomy, which includes SPOs performed through the ankylosed segments and the Ponte, performed through the non-fused regions.

There are also the pedicle subtraction osteotomy (PSO) and the vertebrectomy (VCR). It is considered that an SPO can correct $10^{\circ}$ per segment, a PSO, $35^{\circ}$, and a VCR, $40^{\circ}$ or more, each having its own precise indications and respective complications, which together with improvement of alignment, make them useful procedures (Figure 2). .-9 $^{-9}$

During the planning of an osteotomy, one must consider: 1) the location of the kyphosis, 2) the risk of neurological injury based on the site of the surgery, 3) the number of osteotomies needed to achieve the correction, 4) the ideal location of the osteotomy,

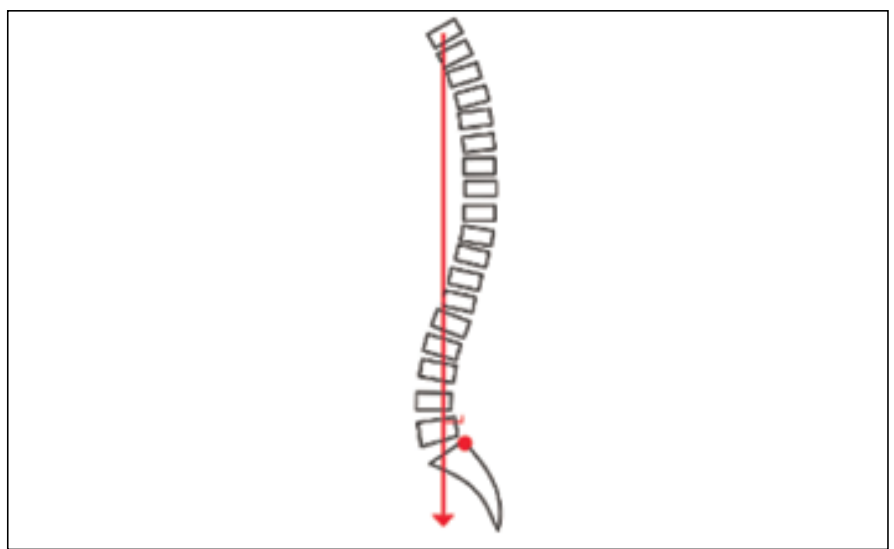

Figure 1. Graphical representation of Sagittal Balance (SB).

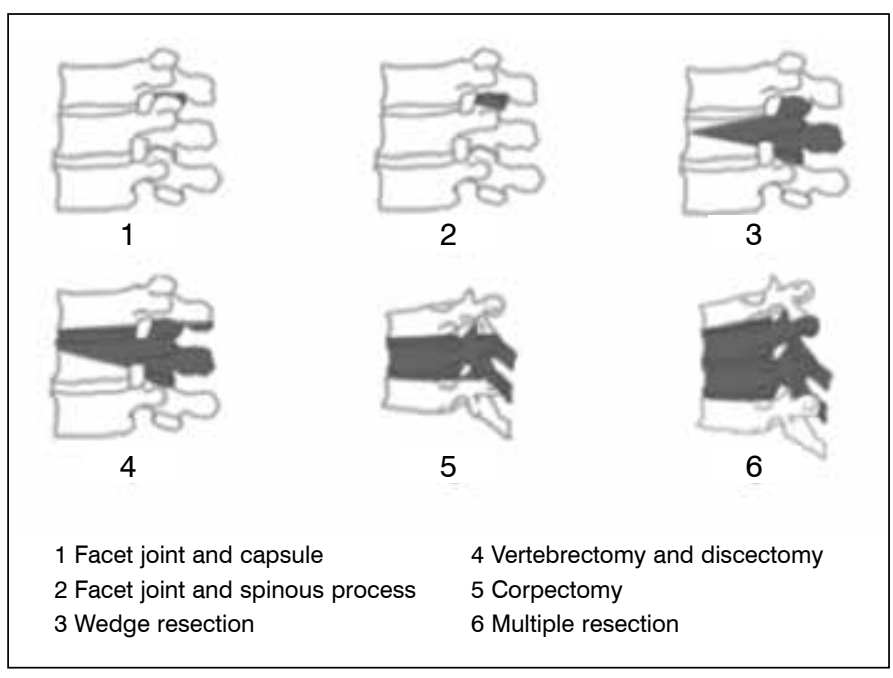

Figure 2. Type and location of the osteotomies.

5) the availability of fixation points and the fusion area, 6) any area of laminectomy present, and 7) bone quality.

The pelvic parameters are extremely important in ensuring optimal correction of sagittal balance..$^{9-13}$

$\mathrm{PI}$ is the angle between the line perpendicular to the sacral promontory and the line from the center of the promontory to the femoral head. The $\mathrm{PI}$ is determined by the ranges of the other parameters $(\mathrm{PI}=\mathrm{PT}+\mathrm{SS})$. PT is the angle between a vertical line and a line from the center of the promontory to the femoral head and measures the alignment between the spine and the center of gravity. The greater the PT, the greater the retraction from the center of gravity. Lastly, the SS is the angle between a horizontal line and a line parallel to the sacral promontory; the smaller the SS, the greater the pelvic retroversion.

Pelvic retroversion is the first step in a cascade of sagittal imbalance and a PT $<25^{\circ}$ facilitates a good quality of life, as does a relationship in which $\mathrm{LL}=\mathrm{PI} \pm 10^{\circ}$.

The objective of this study is to analyze clinical and radiological evolution and the indications and complications of the types of osteotomies in patients which sagittal imbalance caused by post-traumatic kyphosis.

\section{METHODS}

We conducted a prospective, observational, longitudinal, open-label, non-randomized study with a follow-up of 2 to 3 years in 30 patients who underwent surgical correction for loss of balance resulting from posttraumatic kyphosis performed by three spine surgeons between January 2014 and December 2017. The study was approved by the Institutional Review Board as protocol number F-2018-1301-69.

The patients were divided into 3 groups - those who were submitted to SPO, PSO, and VCR surgery, respectively. Data was collected from their medical records (the study participants had signed an informed consent form), including demographic data, such as age and sex, and intervention variables such as osteotomy level, etiology of the deformity, type of surgery (number of screws), fusion level, transoperative bleeding volume, degree of fusion, transoperative and postoperative complications, surgical time, and length of hospitalization. A disability assessment was conducted using the Oswestry questionnaire. 
The degrees of pre- and postoperative kyphosis were measured through an evaluation of digital radiographs and the DICOM ${ }^{\circledR}$ and Surgimap ${ }^{\circledR}$ systems, assessing the angle of segmental kyphosis at the location where the osteotomy was performed. Using the upper end plate of the vertebra above the osteotomy and the lower end plate of the vertebra below the osteotomy as a reference, sagittal balance was measured in a spinogram in which the plumb line of $\mathrm{C} 7$ and the posterior superior edge of the end plate of S1 were defined.

The analysis was performed using descriptive statistics, estimated absolute and relative frequencies, central tendency, and dispersion. The paired t-test and the Wilcoxon signed-rank test, as well as the Pearson Spearman correlation test were performed and $p<0.05$ was accepted as statistically significant, using Epi-Info and Excel programs.

\section{RESULTS}

We reviewed the medical records of 30 patients, 16 males (53.4\%) and 14 females (46.6\%), operated for sagittal balance resulting from post-traumatic kyphosis during the period from January 2014 to December 2017. The average patient age was 50 years (SD 14), with a follow-up of between 2 and 3 years (Table 1 ).

Eleven (36.7\%) underwent SP osteotomies, 17 (56.7\%) were submitted to pedicle subtraction, and $2(6.6 \%)$ underwent vertebrectomies, Most of the injuries $(19,63.3 \%)$ were located between levels L1 and L2 (Table 2).

The average hospital stay was $4 \pm 2$ days, the average transoperative bleeding was $1350 \mathrm{ml}$, and an average of $8 \pm 2$ transpedicle screws were used per surgery, presenting an average correction of $32^{\circ}$ $\pm 5^{\circ}$ with optimal correction of sagittal balance in $23(73.8 \%)$ patients.

Most of the osteotomies performed were at the lumbar level, specifically $8(26.6 \%)$ at $L 1$ and $11(36.7 \%)$ at L2.

As regards the degree of fusion, an optimal level of fusion (remodeling and formation of trabelculae) was observed in all the patients, although it should be noted that the patients submitted to vertebrectomy had a lower average level of fusion than those who underwent SPO and PSO.

The radiological measurements highlighted a kyphosis correction angle of $17^{\circ}$ for SPO, $33^{\circ}$ for PSO, and $39^{\circ}$ for VCR. Among the 3 groups, the modification to the SVA was less in the patients with SPO $(2.88 \mathrm{~cm})$ (Table 2).

Complications like dehiscence of the surgical wound and infection requiring the use of VAC were observed in 4 (13.3\%) and 2 (6.6\%) patients, respectively.

Minimum surgical time was 3 hours and 30 minutes and maximum surgical time was 6 hours, with an average of 4 hours and 20 minutes (Table 3).

There was no statistically significant difference in the preoperative and 2-year follow-up Oswestry disability questionnaire scores

Table 1. Demographic data.

\begin{tabular}{c|c|c}
\hline Variable & Result & $\%$ \\
\hline Total, $\mathrm{N}=$ & 30 & s.d. 14 \\
\hline Age & 50 & 46.6 \\
\hline Male & 14 & 53.4 \\
\hline Female & 16 & 36.7 \\
\hline Osteotomy & 11 & 56.7 \\
\hline Subtraction & 17 & 6.6 \\
\hline Vertebrectomy & 2 & 3.4 \\
\hline Level T9 & 1 & 3.4 \\
\hline Level T10 & 1 & 6.6 \\
\hline Level T11 & 2 & 13.3 \\
\hline Level T12 & 4 & 26.6 \\
\hline Level L1 & 8 & 36.7 \\
\hline Level L2 & 11 & 10.0 \\
\hline Level L3 & 3 &
\end{tabular}

among the three groups. However, the changes produced during the two years of evolution following surgery, in which there is a statistically significant difference in the scores of the different items, reflect considerable improvement, decreasing from an initial index of $73 \%$ to $31 \%$ at two years following pedicle subtraction surgery (Figure 3 ).

Table 2. Radiological measurements prior to surgery and after 2 years of follow-up.

\begin{tabular}{l|c|c|c|c|c}
\hline & $\begin{array}{c}\text { Mean } \\
\text { kyphosis } \\
\text { correction }\end{array}$ & $\begin{array}{c}\text { Preoperative } \\
\text { SVA } \\
\text { (cm) }\end{array}$ & $\begin{array}{c}\text { Postoperative } \\
\text { sVA } \\
\text { (cm) }\end{array}$ & $\begin{array}{c}\text { Mean SVA } \\
\text { correction } \\
(\mathbf{c m})\end{array}$ & $\begin{array}{c}\text { "p" } \\
\text { Value }\end{array}$ \\
\hline SPO $(n=11)$ & $17^{\circ}$ & $3.17+-2.1$ & $0.87+-0.31$ & 2.88 & $>0.05$ \\
\hline PSO $(n=17)$ & $33^{\circ}$ & $12.2+-9.1$ & $4.10+-3.22$ & 7.46 & $<0.05$ \\
\hline VCR $(n=2)$ & $39^{\circ}$ & $11.5+-9-2$ & $3.23+-2.21$ & 6.23 & $>0.05$ \\
\hline
\end{tabular}

SVA (sagittal vertical axis); SPO (Smith-Petersen osteotomy; PSO (pedicle subtraction osteotomy; VCR (vertebrectomy).

Table 3. Surgical events.

\begin{tabular}{c|c|c|c}
\hline & SPO $(\mathrm{n}=11)$ & PSO $(\mathrm{n}=17)$ & VCR $(\mathrm{n}=2)$ \\
\hline Blood loss & $1223 \mathrm{ml}$ & $1459 \mathrm{ml}$ & $1834 \mathrm{ml}$ \\
\hline Surgical time & $2 \mathrm{hrs}$ & $3.5 \mathrm{hrs}$ & $4.5 \mathrm{hrs}$ \\
\hline Hospital stay & 3 days & 3 days & 4 days \\
\hline
\end{tabular}

SPO (Smith-Petersen osteotomy; PSO (pedicle subtraction osteotomy; VCR (vertebrectomy).

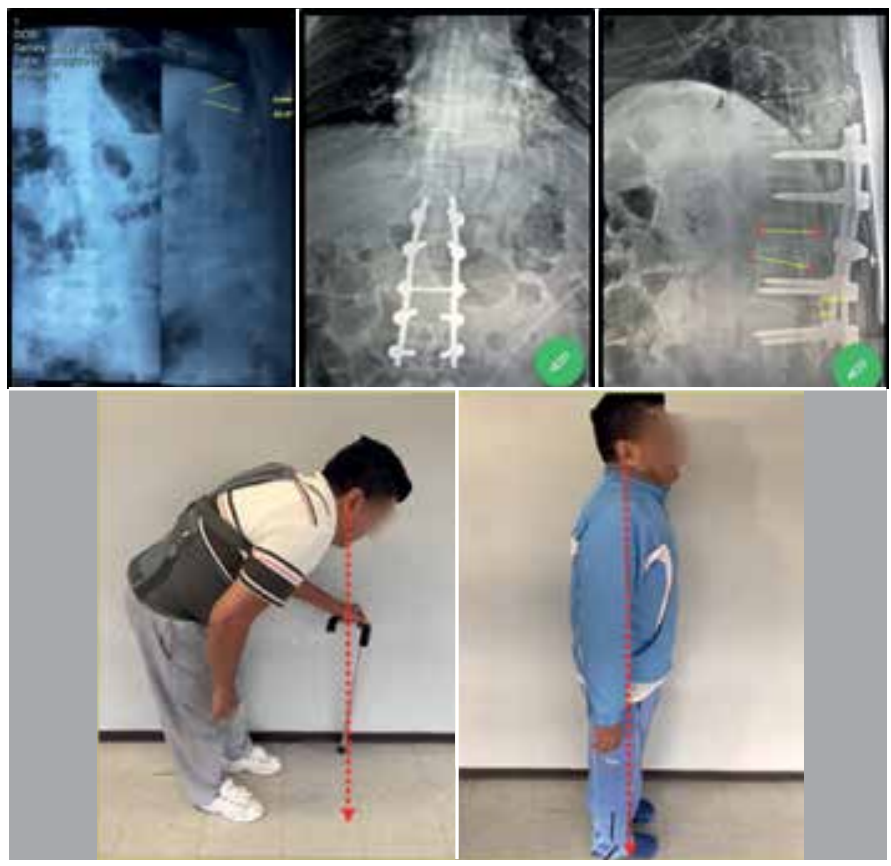

Figure 3. Corrective osteotomy. 2 years of evolution.

\section{CONCLUSIONS}

Sagittal imbalance is a mechanical problem that causes functional disability and chronic pain, altering the quality of life.

The use of corrective osteotomies at the vertebral level significantly reestablishes spinopelvic balance that has been altered by different pathologies, be they degenerative, infectious, or traumatic.

This type of technique allows correction of sagittal imbalance in a single surgical time, achieving corrections that range from $10^{\circ}$ to $40^{\circ}$, depending on the type of osteotomy performed, whether SPO, $\mathrm{PSO}$, or VCR, each of which has its own indications.

Cho, in a study conducted in 2005, compared SPO and PSO osteotomies and observed a correction of $33.0^{\circ} \pm 2^{\circ}$ in the SPOs and $31.7^{\circ} \pm 9.0^{\circ}$ in the PSOs, with blood loss of $1398 \mathrm{ml} \pm 738 \mathrm{ml}$ in the SPOs and $2617 \mathrm{ml} \pm 1645$ in the PSOs, with $4 \%$ postoperative neurological complications. ${ }^{2,5}$

In his 2001 study, Chen, using transpedicle osteotomies to 
correct thoracolumbar kyphosis, most of them in L2 and L3, achieved an average correction of $34.5^{\circ}$ ranging from $15^{\circ}$ to $60^{\circ}$ without presenting neurological complications. ${ }^{10}$

One of the strengths of this study is that it was performed by three spine surgeons, using only a posterior approach and 4-level instrumentation in all cases. It is noteworthy that surgical time has decreased in accordance with the learning curve, currently reaching 3 hours, along with blood loss of $1223 \mathrm{ml}$ to $1834 \mathrm{ml}$ and hospitalization of 96 hours.

A variation in the surgical technique is that, by subtracting the pedicle, a space is created, preserving the cortical layer that, at the moment of compression of the level to be corrected, retracts and generates a protection point towards the root of the level and allows the closure of the osteotomy.

This type of analysis allows the identification of the corrective osteotomy in patients with posttraumatic kyphosis. It is a safe and effective procedure that permits recovery from spinopelvic imbalance, improving the quality of life of the patients.

All authors declare no potential conflict of interest related to this article.

CONTRIBUTION OF THE AUTHORS: Each author made significant individual contributions to this manuscript. AV (0000-0003-1582-5809)* wrote the abstract and provided the translations. JA (0000-0002-5532-5318)* wrote the Methods section and contributed to the Discussion section. SG (0000$0002-0831-849 X)^{\star}$ built the statistical tables, wrote the Results section, and contributed to the Discussion section. GC $(0000-0002-4278-5024)^{\star}$ prepared the Conclusions section based on the Results section and contributed to the Discussion section. *ORCID (Open Researcher and Contributor ID).

\section{REFERENCES}

1. Roussouly P, Nadi C. Sagittal plain deformity: an overview of interpretation and management. Eur Spine J. 2010;19(11):1824-36.

2. Booth $\mathrm{KC}$, Bridwell $\mathrm{KH}$, Lenke LG, Baldus CR, Blanke KM. Complications and predictive factors for the succesful treatment of flatback deformity (fixed sagital imbalance). Spine (Phila Pa 1976). 1999:24(16):1712-20

3. Bridwell KH. Decision making regarding Smith-Petersen vs. Pedicle subtraction osteotomy vs. Vertebral column resection for spinal deformity. Spine (Phila Pa 1976). 2006:31(19 Suppl):S171-8

4. Roussouly P, Gollogly S, Berthonnaud E, Dimnet J. Classification of the normal variation in the sagittal alignment of the human lumbar spine and pelvis in the standing position. Spine (Phila Pa 1976). 2005;30(3):346-53.

5. Cho KJ, Bridwell KH, Lenke LG, Berra A, Baldus C. Comparison of Smith-Petersen versus pedicle substration osteotomy for th correction of fixed sagital imbalance. Spine (Phila Pa 1976). 2005;30(18):2030-7.

6. Lafage V, Schwab F, Vira S, Patel A, Ungar B, Farcy JP. Spino-pelvic parameters after surgery can be predicted: a preliminary formula and validation of standing alignment. Spine (Phila Pa 1976). 2011;36(13):1037-45.
7. Smith-Petersen MN, Larson CB, Aufranc OE. Osteotomy of the spine for correction of flexion deformity in rheumatoid arthritis. Clin Orthop Relat Res. 1969;66:6-9.

8. Lenke LG, O'Leary PT, Bridwell KH, Sides BA, Koester LA, Blanke KM. Posterior vertebral column resection for severe pediatric deformity: mínimum two-year follow-up of thirty five consecutive patients. Spine (Phila Pa 1976). 2009:34(20):2213-21.

9. Voos K, Boachie-Adjei O, Rawlins B. Multiple Vertebral Osteotomies in the Treatment of Rigid Adult Spine Deformities. Spine (Phila Pa 1976). 2001;26(5):526-33.

10. Ing-Ho C, Chien JT, Yu TC. Transpedicular Wedge Osteotomy for Correction of Thoracolumbar Kyphosis in Ankylosing Spondylitis Experience With 78 Patients. Spine (Phila Pa 1976). 2001;26(16):E354-60.

11. Leong JJ, Curtis M, Cartes E, Cowan J, Lehovsky J. Risk neurogical injuries in spinal deformity surgery. Spine (Phila Pa 1976). 2016;41(12):1022-7.

12. Herbert JJ. Vertebral osteotomy technique, indications and results. J Bone Joint Surg. 1948:30A(3):680-9

13. Munting E. Surgical treatment of post-traumatic kyphosis in the toracolumbar spine: indications and technical aspects. Eur Spine J. 2010;19(Suppl 1):69-73. 